Article

\title{
Verification of normal distribution of welding distortions
}

\author{
Damian Grzesiak ${ }^{1, *}$, Jarosław Plichta ${ }^{1}$ \\ 1 Koszalin University of Technology, Poland \\ prof. dr hab. inż. Jarosław Plichta; jarosław.plichta@tu.koszalin.pl \\ * Correspondence: mgr inż. Damian Grzesiak; dmn.grzesiak@gmail.com
}

Received: 25.02.2019; Accepted: 10.03.2019

\begin{abstract}
The aim of this paper is to answer the question of the distribution of welding distortions. The MIG method was used to make 31 butt welds of 0H18N9 sheet metal, of $6 \mathrm{~mm}$ thickness and dimensions 150x350 mm. All joints are made with constant parameters of the welding process. Statistical analysis of the distribution and Kolomogorov-Smirnov test were used in this paper. On the grounds of the analysis it was proved that the distribution of welding deformations is a normal distribution. This justifies the use of experiment planning methods and the use of average values. The relatively high value of the standard deviation makes it necessary to take into account the geometrical parameters of the joint.
\end{abstract}

Keywords: welding distortion; normal distribution test

\section{Introduction}

Welding deformations are an inseparable part of the welding process. The great interest of the scientific community in controlling and prediction of welding distortions has contributed to the creation of many works in which the influence of the basic parameters of the welding process was determined, i.e. voltage, current intensity and welding speed as well as additional factors, e.g. the method of fixing, the number of beads or the welding sequence on the formation of welding distortions [1:6]. Paper [1] investigated the influence of linear energy of the welding process and the number of beads on the resulting welding distortions. The authors proved that the greatest accumulation of deformations occurs when the first four beads are made regardless of the value of linear energy. Prediction of welding distortions is not possible without computer models, which significantly reduce the cost of analysis and allow to follow the deformation of welded elements step by step. In engineering research, experimental design methods are used, which are described in more detail in [9]. The cited methodology was used in the works $[7,8,10]$. It should be noted that the use of experiment planning methods requires manipulation of the average results of the experiment. This means that it is necessary to know the distribution of a random variable, because only for the normal distribution the largest part of the results is in the vicinity of the average value. In the works $[2 \div 6]$ authors presented the results of created computer models of the process of welding of the test joints, according to the adopted procedures. A common feature of all the works cited is a certain deviation

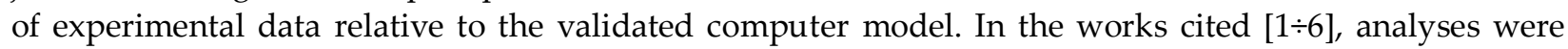
carried out on the basis of one experimental trial without repetitions at a given measurement point. It should be noted whether the obtained experimental results are reliable in a statistical sense - what distribution describes the welding distortions and what number of repetitions at a given measurement point, allows to maintain the reliability of the obtained results. This study aims to illustrate the problem of reliability of results from experimental trials without repetition.

\section{Research methodology}

The analysis of the welding distortions distribution was carried out on samples made of 0H18N9 steel sheet with a thickness of $6 \mathrm{~mm}$ and dimensions $150 \times 350 \mathrm{~mm}$ according to PN-EN ISO 15614. Samples were cut with a laser beam while maintaining the direction of rolling along the long side of the sample. Figure 1a shows the geometry of the welding groove prepared by machining. 
At both ends of the samples, plates were welded for the proper start and end of the welding process. Before making the joint, the samples were thoroughly cleaned and degreased with acetone. The joints were made at the robotic station of the Panasonic company Robot TM2000 (Fig. 1b), equipped with dedicated software for acquiring output parameters. The clamping of the samples was carried out with four clamps. The samples were made using method 135 in the M13 gas shield. An additional material was used in the form of 316LSi ø1,2 $\mathrm{mm}$ wire (number of the cast 264664-62023). The inclination angle of the burner was $16^{\circ}$. Burner oscillation parameters: $2 \mathrm{~mm}$ axial deflection, $2 \mathrm{~Hz}$ frequency. The joints were made with fixed parameters, which are shown in Table I.

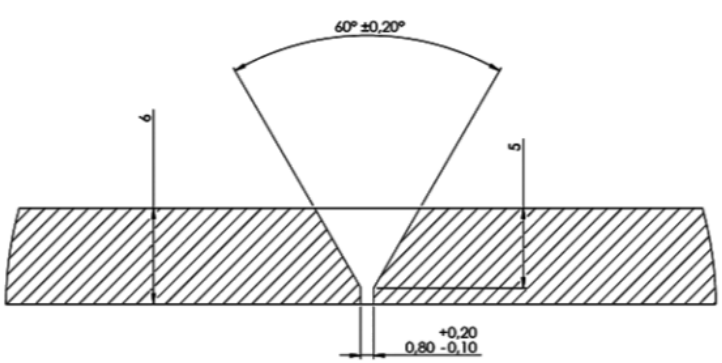

(a)

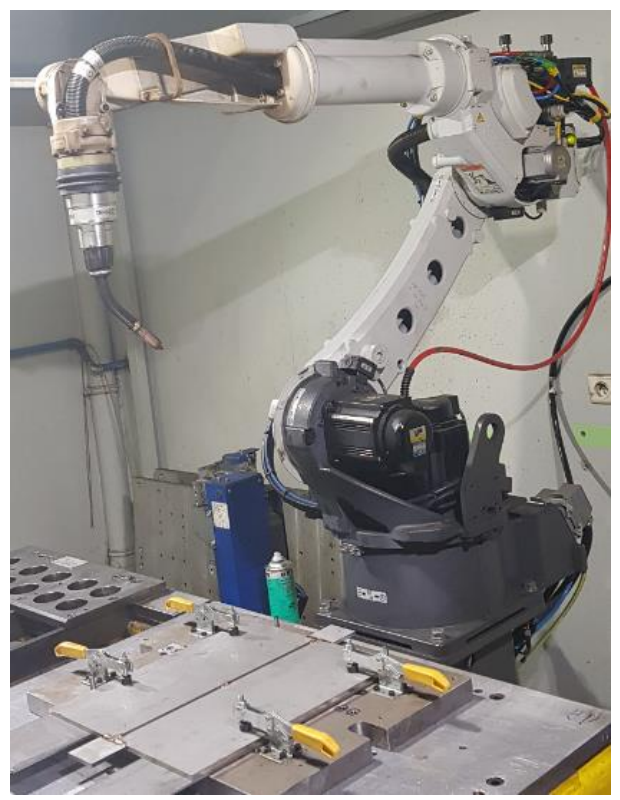

(b)

Fig. 1. A research stand: a) sample cross-section, b) view of the test stand

Table I. Welding process parameters

\begin{tabular}{|c|c|c|c|c|c|c|}
\hline $\begin{array}{l}\text { Set current } \\
\text { intensity }\end{array}$ & $\begin{array}{l}\text { Actual current } \\
\text { intensity }\end{array}$ & Set voltage & $\begin{array}{l}\text { Actual } \\
\text { voltage }\end{array}$ & $\begin{array}{l}\text { Wire feeding } \\
\text { speed }\end{array}$ & $\begin{array}{c}\text { Speed } \\
\text { of travel }\end{array}$ & $\begin{array}{c}\text { Actual linear } \\
\text { energy }\end{array}$ \\
\hline A & $\mathbf{A}$ & V & V & $\mathrm{m} / \mathrm{min}$ & $\mathrm{m} / \mathrm{min}$ & $\mathrm{kJ} / \mathrm{mm}$ \\
\hline 172 & 215 & 21 & 21 & 7,31 & 0,4 & 0,68 \\
\hline
\end{tabular}

Finished samples were put into packages of 3 pieces, after which they were allowed to cool in the air. The tests were carried out at an ambient temperature of $28^{\circ} \mathrm{C}$ and humidity of $48 \%$. After 48 hours, a visual test was carried out according to the PN-EN ISO 5817 standard. Analyzed joints obtained the B quality level. With Wenzel CMM coordinate machine was acquire surface flatness data.

The null and alternative hypothesis formulated for the purposes of this analysis:

- $\mathrm{H} 0$ - the distribution of welding distortions is characterized by a near-normal distribution.

- $\mathrm{H} 1$ - the distribution of welding distortions is not characterized by a near-normal distribution.

\section{Measurement results and statistical analysis}

Table II presents the results of measuring the surface flatness of the analyzed samples. On the basis of data from Table II, a statistical analysis of the normality of the flatness distribution of the surface of welding samples was carried out. Table III presents the results of basic distribution parameters as well as results of skewness and kurtosis tests.

Table IV presents a frequency distribution of the test results along with the parameters necessary for the Kolmogorov-Smirnov test.

In order to verify the normality of the distribution, the statistics of Kolmogorov-Smirnov were used at the significance level of $\alpha=0.05$, which presents the formula (1):

$$
\sqrt{N} D_{n} \leq T_{K-S}
$$

where:

- $\mathrm{N}$ - number of observations, 
- $D_{n}$ - the maximum of probability differences in a given class $D_{n}=\max \left|C_{x}-P_{x}\right|$,

- TK-S - critical value of the Kolmogorov-Smirnov test.

Table II. Results of measurement of surface flatness of samples, results in mm

\begin{tabular}{cccccccccc}
\hline No. & Result & No. & Result & No. & Result & No. & Result & No. & Result \\
\hline 1 & 2,132 & 8 & 1,058 & 15 & 3,304 & 22 & 1,104 & 29 & 1,515 \\
2 & 2,272 & 9 & 3,088 & 16 & 1,82 & 23 & 1,521 & 30 & 1,243 \\
3 & 1,495 & 10 & 2,717 & 17 & 2,739 & 24 & 1,454 & 31 & 2,458 \\
4 & 0,606 & 11 & 2,717 & 18 & 2,436 & 25 & 4,158 & & \\
5 & 2,105 & 12 & 2,778 & 19 & 2,032 & 26 & 3,985 & & \\
6 & 2,219 & 13 & 2,338 & 20 & 1,93 & 27 & 0,959 & & \\
7 & 1,595 & 14 & 2,464 & 21 & 1,891 & 28 & 1,608 & & \\
\hline
\end{tabular}

Table III. Results of basic parameters of normal distribution

\begin{tabular}{ccccc}
\hline Average & Unbiased variance & $\begin{array}{c}\text { Unbiased standard } \\
\text { deviation }\end{array}$ & Kurtosis & Skewness \\
\hline $\bar{x}$ & $\sigma^{2}$ & $\sigma$ & $K$ & $S$ \\
\hline 2,121 & 0,692 & 0,832 & 3,132 & 0,547 \\
\hline
\end{tabular}

Table IV. Frequency distribution of test results

\begin{tabular}{|c|c|c|c|c|c|c|c|}
\hline 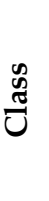 & 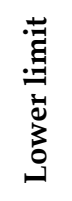 & 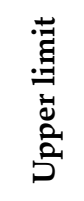 & 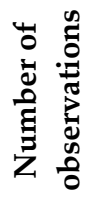 & 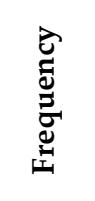 & 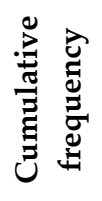 & 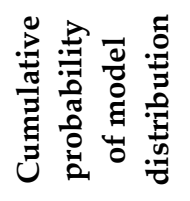 & 导 \\
\hline $\mathrm{k}$ & $G_{d}$ & $G_{g}$ & $N$ & $C$ & $C_{x}$ & $P_{x}$ & $\left|C_{x}-P_{x}\right|$ \\
\hline 1 & 0,6 & 1,2 & 4 & 0,13 & 0,13 & 0,13 & 0,00 \\
\hline 2 & 1,2 & 1,8 & 7 & 0,23 & 0,36 & 0,35 & 0,01 \\
\hline 3 & 1,8 & 2,4 & 9 & 0,29 & 0,65 & 0,63 & 0,02 \\
\hline 4 & 2,4 & 3,0 & 7 & 0,23 & 0,88 & 0,86 & 0,02 \\
\hline 5 & 3,0 & 3,6 & 2 & 0,06 & 0,94 & 0,96 & 0,02 \\
\hline \multirow[t]{2}{*}{6} & 3,6 & 4,2 & 2 & 0,06 & 1,000 & 0,99 & 0,01 \\
\hline & & Sum & 31 & 1,000 & & & \\
\hline
\end{tabular}

By substituting values from Table IV to Formula (1), we obtain an inequality that was met for the critical value of the Kolmogorov-Smirnov test $0.111 \leq 0.238$ at the significance level of $\alpha=0.05$. Figure 2 presents a histogram and a graph of empirical and theoretical distribution of the function with $\mathrm{N}$ parameters $(2,121,832)$.

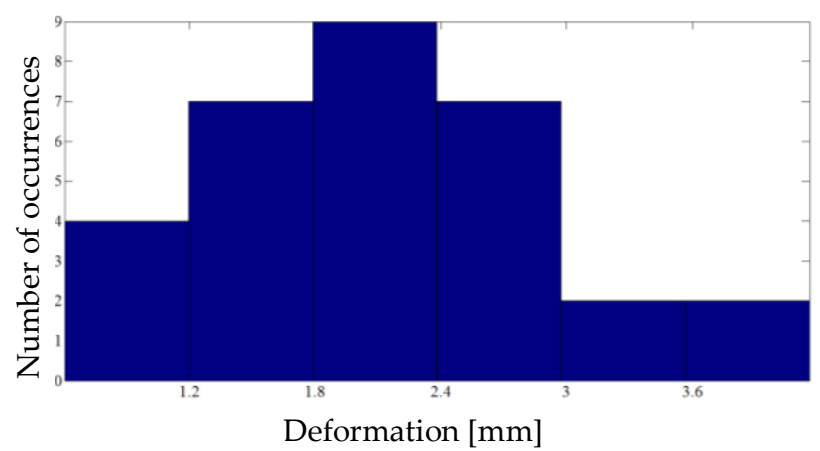

(a)

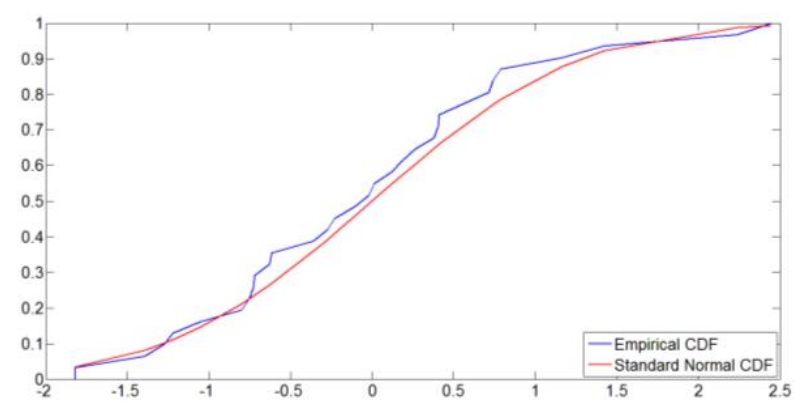

(b)

Fig 2. Results of distribution analysis: a) histogram; b) summary of theoretical and empirical distributions 


\section{Analysis of the results}

The results of the Kolomogorov-Smirnov test indicate the lack of grounds for rejecting the null hypothesis $\left(\mathrm{H}_{0}\right)$ - the normality of the distribution of welding distortions at the significance level of $\alpha=0.05$. Parameters of the analyzed distribution were: average $2.121 \mathrm{~mm}$, standard deviation $0.832 \mathrm{~mm}$. The value of the kurtosis coefficient indicates the leptokurtic shape of the bell curve in relation to the mesokurtic model distribution. The value of the skewness coefficient of 0.547 indicates the right-sided asymmetry of the distribution. In Figure 2a, the right-sided chart shift is noticeable due to two results from Class 6 in Table IV, which may be the extreme points of normal distribution. The analysis indicates no grounds for rejecting these results in this study. Due to the right-hand offset of the distribution, the three-sigm rule cannot be applied. This would involve a logical mistake because the flatness of the surface cannot reach negative values. It is worth noting that the application of the two-sigm rule, which is $2.121 \pm 1.664 \mathrm{~mm}$, can be found in $95.4 \%$ of the observations.

\section{Conclusions}

Based on the analysis, the following conclusions were made:

1. Confirmation of the normality of the welding distortions distribution, justifies the use of experiment planning methods and the use of average values.

2. Near the average value in the tolerance of one standard deviation, the largest part of the observations is found.

3. The obtained mean values and standard deviation allow the selection of the appropriate number of repetitions to the plan of the experiment.

4. Apart from technological parameters, the geometrical parameters of the joint and the tolerance of their execution have a significant influence on the welding distortions. This is due to the relatively large value of the standard deviation, which is $39 \%$ of the average value.

\section{References}

1. Adamczuk P.C.; Machado I.G.; Mazzaferro J.A.E. Methodology for predicting the angular distortion in multipassbutt-jointwelding. Journal of Materials Processing Technology 2017, Vol. 240, 305-313. [CrossRef]

2. Deng D.; Liang W.; Murakawa H. Determination of welding deformation in fillet-welded joint by means of numerical simulation and comparison with experimental measurements. Journal of Materials Processing Technology 2007, Vol. 183, 219-225. [CrossRef]

3. Gannon L.; Liu Y.; Pegg N.; Smith M. Effect of welding sequence on residual stress and distortioninflat-bar stiffened plates. Marine Structures 2010, Vol. 23, 385-404. [CrossRef]

4. Guangming F.; Marcelo I.L.; Menglan D.; Segen F.E. Influence of the welding sequence on residual stress and distortion of fillet welded structures. Marine Structures 2016, Vol. 46, 30-55. [CrossRef]

5. Tian L.; Luo Y.; Wang Y.; Wu. X. Prediction of transverse and angular distortions of gas tungsten arc bead-onplate welding using artificial neural network. Materials and Design 2014, Vol. 54, 458-472. [CrossRef]

6. Liang W.; Murakawa H. Predicting Welding Distortion in a Panel Structure with Longitudinal Stiffeners Using Inherent Deformations Obtained by Inverse Analysis Method. Hindawi Publishing Corporation, The Scientific World Journal, Vol. 2014, Article ID 601417, 8 pages. [CrossRef]

7. Pałubicki S.; Karpiński S. Wpływ energii liniowej na skłonność powstawania pęknięć gorących w procesie spawania stali S355J2WP metodą 135, Welding Technology Review 2015, vol. 87(4), 21-27. [CrossRef]

8. Poch K. Plany eksperymentu. Opracowanie planu oceny czułości badań magnetyczno-proszkowych. Welding Technology Review, 2012, Vol. 87 (4), 41-48. [CrossRef]

9. Kukiełka L. Podstawy badań inżynierskich, Wydawnictwo Naukowe PWN, Warszawa 2002.

10. Urbański T. Węzeł hybrydowy - prognozowanie odkształcenia kątowego łącznika na podstawie planowanego eksperymentu trójwartościowego, Welding Technology Review 2017, Vol. 89(9), 6-13. [CrossRef]

(C) 2019 by the authors. Submitted for possible open access publication under the terms and conditions of the Creative Commons Attribution (CC BY) license (http://creativecommons.org/licenses/by/4.0/). 